\title{
CYCLO-(TRP-PHE) DIKETOPIPERAZINES FROM THE ENDOPHYTIC FUNGUS Aspergillus versicolor ISOLATED FROM Piper aduncum ${ }^{\#}$
}

\author{
Juliana R. Gubiani ${ }^{a}$, Helder L. Teles ${ }^{\mathrm{b}}$, Geraldo H. Silvac, Maria Cláudia M. Young ${ }^{\mathrm{d}}$, José O. Pereira ${ }^{\mathrm{e}}$, Vanderlan S. Bolzani ${ }^{\mathrm{a}}$ \\ and Angela R. Araujo ${ }^{a, *}$ \\ aDepartamento de Química Orgânica, Instituto de Química, Universidade Estadual Paulista, 14800-900 Araraquara - SP, Brasil \\ bDepartamento de Ciências Biológicas, Universidade Federal do Mato Grosso, 78735-901 Rondonópolis - MT, Brasil \\ 'Instituto de Ciências Exatas e Tecnológicas, Universidade Federal de Viçosa, 38810-000 Rio Paranaíba - MG, Brasil \\ ${ }^{\mathrm{d}}$ Núcleo de Pesquisa em Fisiologia e Bioquímica, Instituto de Botânica, 01061-970 São Paulo - SP, Brasil \\ ${ }^{\mathrm{e} F a c u l d a d e}$ de Ciências Agrárias, Universidade do Amazonas, 69077-000 Manaus - AM, Brasil
}

Recebido em 10/05/2016; aceito em 11/08/2016; publicado na web em 02/09/2016

\begin{abstract}
Six known compounds, three peptide derivatives: cyclo-(tryptophyl-phenylalanyl) (2), diketopiperazine dimer WIN 64821 (3) and 3-hydroxy-15H-tryptophenaline (4), one adenine derivative: 2-hydroxy-6-N-isopentenyl-adenine (5), one phtalide derivative: 4-methoxyphtalide (1) and one benzoic acid derivative: 3-hydroxy-4-(1-hydroxy-1,5-dimethyl-hexyl) benzoic acid (6), were isolated from the ethyl acetate extract of the endophytic fungus Aspergillus versicolor associated with the Piper aduncum plant. Their structures were determined on the basis of detailed interpretation of $1 \mathrm{D}$ and 2D NMR spectra and in comparison with works reported in the literature. This paper, in effect, deals with the first report of these compounds in A. versicolor.
\end{abstract}

Keywords: cyclo-(Trp-Phe) diketopiperazines; endophytic fungus; Aspergillus versicolor; Piper aduncum.

\section{INTRODUCTION}

In the quest for new bioactive natural products, a heightening degree of attention has been devoted to endophytic organisms, which are defined as "a group of diverse, polyphyletic microorganisms that internally infect living plant tissues without causing any noticeable symptom of infection, while living in mutualistic association with plants for a part of their life cycle". ${ }^{1}$ They are, therefore, regarded as an emerging source of discovery of biologically active secondary metabolites having antibiotic, antioxidant, anticancer, antiviral, immunosuppressive and antidiabetic activities, which have been drawing an increasingly wide interest in recent times. ${ }^{2}$

Cyclic dipeptides, also known as diketopiperazines (DKPs), are quite common in nature and comprise an important class of the secondary metabolites that are mainly produced by microorganisms including Aspergillus, Penicillium, Pestalotiopsis, and Chromocleista. This class of alkaloids is derived from different amino acids and from one or more isoprene units. Many natural products with the DKPs scaffold have been isolated and are found to exhibit a wide range of biological activities such as antibacterial, antialga, antivirus, anti-oxidation, cytotoxicity, plant growth regulation, immune regulation and antifungal agents. It is noteworthy that DKPs play an important role in the regulatory mechanism of quorum sensing as signal molecules and have become a research hot point in ecological chemistry. For instance, cyclo-(Trp-Phe) has been therapeutically used in the modulation of potassium ion membrane channels. ${ }^{3}$

The core aim of this article lies in the isolation of A. versicolor from leaves of $P$. aduncum, and the identification of three peptide derivatives: cyclo-(tryptophyl-phenylalanyl) (2), diketopiperazine dimer WIN 64821 (3) and 3-hydroxy-15H-tryptophenaline (4), one adenine derivative: 2 -hydroxy-6-N-isopentenyl-adenine (5), one phtalide derivative: 4-methoxyphtalide (1) and one benzoic acid

*e-mail: araujoar@iq.unesp.br

\#This paper is part of the PubliSBQ Special Issue in honor of the late Prof. Angelo da Cunha Pinto. derivative: 3-hydroxy-4-(1-hydroxy-1,5-dimethyl-hexyl) benzoic acid (6), isolated from $P$. aduncum.

\section{EXPERIMENTAL SECTION}

\section{General experimental procedures}

${ }^{1} \mathrm{H}$ NMR (500 MHz), ${ }^{13} \mathrm{C}$ NMR (125 MHz), HMBC, HSQC and COSY experiments were recorded on a Varian INOVA-500 spectrometer using the residual non-deuterated $\left(\mathrm{CDCl}_{3}\right.$ and DMSO- $\left.d_{6}\right)$ signal as an internal standard. Mass spectra were measured using a Micromass spectrometer set to ESI mode [triple quadrupole model (Quattro-LC, Manchester, UK)]. TLC analyses were performed using Merck silica gel 60 (230 mesh) and precoated silica gel $60 \mathrm{PF}_{254}$. Spots on the TLC plates were visualized either under UV light or by spraying with anisaldehyde- $\mathrm{H}_{2} \mathrm{SO}_{4}$ reagent followed by heating at $120^{\circ} \mathrm{C}$. Analytical HPLC was performed on a Varian Prostar 330 system using a Phenomenex Luna $\mathrm{C}_{18}$ column $(250 \mathrm{~mm}$ x $4.6 \mathrm{~mm}$, $5 \mu \mathrm{m})$. Preparative HPLC was performed by means of a Shimadzu SPD-M20A system using an Alltech ${ }^{\circledR} \mathrm{C}_{18}$ column $(250 \mathrm{~mm} \times 10 \mathrm{~mm}$, $8 \mu \mathrm{m})$, and Alltech ${ }^{\circledR}$ phenyl-butyl column $(250 \mathrm{~mm}$ x $10 \mathrm{~mm}, 5 \mu \mathrm{m})$. Column chromatography (CC) was performed over reversed-phase silica gel, 230-400 and 70-230 mesh (Merck).

\section{Plant material}

Authenticated P. aduncum (Piperaceae) was stored and collected at NuBBE's greenhouse, São Paulo, Brazil, in 2001. The identification of $P$. aduncum was carried out by Professor Inês Cordeiro (Institute of Botany, São Paulo, Brazil), and a voucher specimen was kept at the Herbarium of São Paulo Botanical Garden, Brazil (Voucher $\mathrm{N}^{\circ}$ Cordeiro PAO). ${ }^{4}$

\section{Fungal isolation and identification}

The endophytic fungus $A$. versicolor was isolated in line with the 
previously described procedure. ${ }^{5}$ The pure fungal strain was stored as Aspergillus versicolor in the $\mathrm{NuBBE}$ fungi collection at the Institute of Chemistry in Araraquara, Brazil (kept in sterile water at $\left.25^{\circ} \mathrm{C}\right) .{ }^{6} \mathrm{The}$ pure A. versicolor culture was classified by Dr. José Odair Pereira.

\section{Cultivation and isolation of metabolites of $A$. versicolor}

The endophytic fungus strain A. versicolor was cultivated in 35 Erlenmeyer flasks, each containing $8.0 \mathrm{~g}$ of potato extract, $4.0 \mathrm{~g}$ dextrose and $200 \mathrm{~mL}$ distilled water (PDB) which were autoclaved at $121{ }^{\circ} \mathrm{C}$ for $40 \mathrm{~min}$. Approximately 10 small pieces $(1 \mathrm{x} 1 \mathrm{~cm})$ of PDA medium, from the Petri dish containing biomass of the $A$. versicolor isolated were inoculated into each flask and the flasks were sealed with cotton to permit aerobic growth. Following incubation for 28 days at $25^{\circ} \mathrm{C}$ in rotary shakers at $150 \mathrm{rpm}$, the mycelia biomass accumulated in the flasks was separated from the aqueous medium by filtration, and the filtrate was subsequently partitioned with ethyl acetate $(3 \times 2.5 \mathrm{~L})$. The organic phase was subjected to drying with $\mathrm{MgSO}_{4}$, filtered and concentrated to yield $0.680 \mathrm{~g}$ of crude extract.

The crude EtOAc extract was fractioned by $\mathrm{C}_{18} \mathrm{RPCC}$ and eluted with an $\mathrm{H}_{2} \mathrm{O}-\mathrm{CH}_{3} \mathrm{OH}$ 95:05 (150 mL), 90:10 (150 mL), 85:15 $(150 \mathrm{~mL}), 80: 20(150 \mathrm{~mL}), 75: 25(150 \mathrm{~mL}), 70: 30(150 \mathrm{~mL}), 65: 35$ (150 mL), 60:40 (150 mL), 55:45 (150 mL), 50:50 (150 mL), 45:55 (150 mL), 40:60 (150 mL), 30:70 (150 mL), 20:80 (150 mL), 10:90 $(150 \mathrm{~mL}), 100 \% \mathrm{CH}_{3} \mathrm{OH}(150 \mathrm{~mL}), 50: 50 \mathrm{CH}_{3} \mathrm{OH}: \mathrm{EtOAc}(150 \mathrm{~mL})$ and $100 \%$ EtOAc $(150 \mathrm{~mL})$ giving rise to 18 fractions (Fr.1-Fr.18). The Fr.6 Fraction $\left(20.2 \mathrm{mg}\right.$ ) was separated by HPLC using Alltech ${ }^{\circledR}$ $\mathrm{C}_{18}$ column ( $\left.8 \mu \mathrm{m}, 250 \mathrm{~mm} \times 10 \mathrm{~mm}\right)$ and $\mathrm{H}_{2} \mathrm{O}: \mathrm{CH}_{3} \mathrm{CN}$ 80:20 as eluent for $60 \mathrm{~min}$ at $12.0 \mathrm{~mL} / \mathrm{min}$, resulting in 11 further subfractions (Fr.6-A-Fr.6-K). The Fr.6-K subfraction was identified as compound $1\left(0.4 \mathrm{mg}, \mathrm{R}_{\mathrm{t}}=55 \mathrm{~min}\right)$. The Fr.9 Fraction $(75.4 \mathrm{mg})$ was found to present a white precipitate upon concentration, which was then separated and identified as compound 2 (60.4 $\mathrm{mg})$. Following the separation of the white precipitate, the Fr.9 fraction was in turn separated by HPLC using Alltech ${ }^{\circledR}$ phenyl-butyl column $(5 \mu \mathrm{m}, 250 \mathrm{~mm}$ x $10 \mathrm{~mm})$ and $\mathrm{H}_{2} \mathrm{O}: \mathrm{CH}_{3} \mathrm{CN}$ 77:23 as eluent for $60 \mathrm{~min}$ at $12.0 \mathrm{~mL} / \mathrm{min}$, which led to a further group of 7 subfractions (Fr.9-A-Fr.9-G). The Fr.9-F subfraction was identified as compound $4\left(2.2 \mathrm{mg}, \mathrm{R}_{\mathrm{t}}=43.0 \mathrm{~min}\right)$. The Fr.13 Fraction $(63.3 \mathrm{mg})$ was separated by HPLC using Alltech phenyl-butyl column $(5 \mu \mathrm{m}, 250 \mathrm{~mm} \times 10 \mathrm{~mm})$ and $\mathrm{H}_{2} \mathrm{O}: \mathrm{CH}_{3} \mathrm{CN}: \mathrm{HAc}$ 30:70:0.02 as eluent for $60 \mathrm{~min}$ at $15.0 \mathrm{~mL} / \mathrm{min}$, giving rise to $5 \mathrm{sub}$ fractions (Fr.13-A-Fr.13-E). The Fr.13-E and Fr.13-B subfractions were identified as compound $\mathbf{3}\left(5.2 \mathrm{mg}, \mathrm{R}_{\mathrm{t}}=31.0 \mathrm{~min}\right)$, respectively and 6 (30.1 mg, $\left.R_{t}=12.0 \mathrm{~min}\right)$. Fraction Fr.5 (19.7 mg), was further separated by HPLC using Alltech ${ }^{\circledR} \mathrm{C}_{18}$ column $(8 \mu \mathrm{m}, 250 \mathrm{~mm}$ x 10 $\mathrm{mm}$ ) and $\mathrm{H}_{2} \mathrm{O}: \mathrm{CH}_{3} \mathrm{CN} 85: 15$ as eluent for $60 \mathrm{~min}$ at $12.0 \mathrm{~mL} / \mathrm{min}$, leading to 3 subfractions (Fr.5-A-Fr.5-C). The Fr.5-A subfraction was identified as compound $\mathbf{5}\left(1.2 \mathrm{mg}, \mathrm{R}_{\mathrm{t}}=16.0\right.$ at $\left.19.0 \mathrm{~min}\right)$

\section{RESULTS AND DISCUSSION}

The EtOAc extract of $A$. versicolor cultivated in sterilized PDB liquid medium led to the isolation of six compounds. The structures of the compounds were elucidated using 1-D, 2-D NMR (Table 1 and 2), MS techniques were also carried out and comparison was made with the literature data. ${ }^{7-12}$ The compounds were identified as three peptide derivatives: cyclo-(tryptophyl-phenylalanyl) (2), diketopiperazine dimer WIN 64821 (3), 3-hydroxy-15H-tryptophenaline (4) and 2-hydroxy-6-N-isopentenyl-adenine (5), 4-methoxyphtalide (1) and 3-hydroxy-4-(1-hydroxy-1,5-dimethyl-hexyl) benzoic acid (6) (Figure 1).

The molecular formula $\mathrm{C}_{9} \mathrm{H}_{8} \mathrm{O}_{3}$ of compound 1 was established by ${ }^{13} \mathrm{C}$ NMR and HREIMS analysis, which showed the protonated molecular ion peak $[\mathrm{M}+\mathrm{H}]^{+}$at $\mathrm{m} / z, 165.0597$ (Calcd. to $\mathrm{C}_{9} \mathrm{H}_{8} \mathrm{O}_{3}$ 165.0552) and indicated six degrees of unsaturation.

The ${ }^{13} \mathrm{C}$ NMR (Table 1) spectra of $\mathbf{1}$ when analyzed in combination with HSQC data, indicated the presence of six aromatic carbon, one methoxyl, one methylenic carbinolic and one carbonyl group.

The ${ }^{1} \mathrm{H}$ NMR spectra indicated the presence of three aromatic signals at $\delta_{\mathrm{H}} 7.36(\mathrm{br} d, J=8.0 \mathrm{~Hz}, \mathrm{H}-5), 7.56(t, J=8.0 \mathrm{~Hz}, \mathrm{H}-6)$, and 7.41 (brdd, $J=8.0,0.5 \mathrm{~Hz}, \mathrm{H}-7$ ), indicating the aromatic system 1,2,3-trisubstituted ring. Additionally, the ${ }^{1} \mathrm{H}$ NMR showed two signals at $\delta_{\mathrm{H}} 3.90(s, \mathrm{H}-10)$ and $\delta_{\mathrm{H}} 5.35(s, \mathrm{H}-3)$ characteristic of aromatic methoxyl and methylene proton, respectively. Thus, compound $\mathbf{1}$ was identified as 4-methoxyphtalide previously isolated from the endophytic fungus Pezicula sp. and Streptomyces strains. ${ }^{7}$

The molecular formula $\mathrm{C}_{20} \mathrm{H}_{19} \mathrm{~N}_{3} \mathrm{O}_{2}$ of compound 2 was established by ${ }^{13} \mathrm{C}$ NMR and HREIMS analysis, which showed the protonated molecular ion peak $[\mathrm{M}+\mathrm{H}]^{+}$at $\mathrm{m} / \mathrm{z} 334.1520$ (Calcd. to $\left.\mathrm{C}_{20} \mathrm{H}_{19} \mathrm{~N}_{3} \mathrm{O}_{2} 334.1555\right)$ and the ion peak $[2 \mathrm{M}+\mathrm{H}]^{+}$at $\mathrm{m} / \mathrm{z}$ 667.3076, and indicated thirteen degrees of unsaturation.

The ${ }^{1} \mathrm{H}$ NMR not only indicated an indole ring related to proton signals $\delta_{\mathrm{H}} 6.95\left(d, J=2.5 \mathrm{~Hz}, \mathrm{H}-2, \delta_{\mathrm{C}} 124.4\right), \delta_{\mathrm{H}} 7.48(d, J=8.0$ $\left.\mathrm{Hz}, \mathrm{H}-4, \delta_{\mathrm{C}} 118.7\right)$ and $\delta_{\mathrm{H}} 7.31\left(d, J=8.0 \mathrm{~Hz}, \mathrm{H}-7, \delta_{\mathrm{C}} 111.3\right)$, but also implied a monosubstituted benzene ring associated with proton signals at $\delta_{\mathrm{H}} 7.15\left(m, \mathrm{H}-19 / \mathrm{H}-23, \delta_{\mathrm{C}} 128.0\right), \delta_{\mathrm{H}} 6.70(d d, J=8.0,1.5$ $\left.\mathrm{Hz}, \mathrm{H}-20 / \mathrm{H}-22, \delta_{\mathrm{C}} 128.0\right)$ and $\delta_{\mathrm{H}} 7.17\left(m, \mathrm{H}-21, \delta_{\mathrm{C}} 126.3\right)$ The two carbonyl groups at $\delta_{\mathrm{C}} 166.2(\mathrm{C}-13)$ and $\delta_{\mathrm{C}} 166.8(\mathrm{C}-16)$ combined with the signals at $\delta 7.69(d, J=2.0 \mathrm{~Hz}, \mathrm{NH}-15)$ and $\delta 7.89(d, J=2.0$ $\mathrm{Hz}, \mathrm{NH}-12$ ), allowed us to identify compound $\mathbf{2}$ as cyclo-(tryptophylphenylalanyl) or cyclo (L-Trp-L-Phe) previously isolated from the endophytic fungus Penicillium sp. in $1996\left([\alpha]^{20}{ }_{\mathrm{D}}-254.9\right.$ (c 1.0, $\mathrm{MeOH})$ ). However, in our case, the optical rotation values of $\mathbf{2}$ was $[\alpha]_{D}^{26}-113.0(c 0.50, \mathrm{MeOH})$, respectively. In fact, this result, in effect, suggests that compound 2 bears the same absolute configuration as the compound isolated from Penicillium sp. ${ }^{8}$

The molecular formula $\mathrm{C}_{40} \mathrm{H}_{36} \mathrm{~N}_{6} \mathrm{O}_{4}$ of compound 3 was established by ${ }^{13} \mathrm{C}$ NMR and HREIMS analyses, and was seen to present the protonated molecular ion peak $[\mathrm{M}+\mathrm{H}]^{+}$at $\mathrm{m} / \mathrm{z}, 665.2885$ (Calcd. to $\mathrm{C}_{40} \mathrm{H}_{36} \mathrm{~N}_{6} \mathrm{O}_{4} 665.2876$ ) and indicating twenty-six degrees of unsaturation.

It is worth pointing out the remarkable similarities that were found between the ${ }^{1} \mathrm{H}$ NMR spectra of $\mathbf{3}$ and $\mathbf{2}$, with the decrease observed in the extension of the tryptophan aromatic amino acid through the reduction of $\Delta^{2-3}$ present in the indole system besides the connection of $\mathrm{C}-2\left(\delta_{\mathrm{C}} 79.8\right)$ to $\mathrm{NH}-12$. This connection was confirmed by the correlation in $\mathrm{HMBC}$ experiment of $\mathrm{H}-2\left[\delta_{\mathrm{H}} 4.95(s)\right]$ with $\mathrm{C}-8\left(\delta_{\mathrm{C}}\right.$ $129.8)$ and $\mathrm{C}-9\left(\delta_{\mathrm{C}} 148.7\right)$, and $\mathrm{H}-10\left[\delta_{\mathrm{H}} 3.17(d d, J=14.0 ; 8.5 \mathrm{~Hz}\right.$, $\mathrm{H}-10 \mathrm{a})$ and $\left.2.80(d d, J=14.0 ; 8.5 \mathrm{~Hz}, \mathrm{H}-10 \mathrm{~b}) \delta_{\mathrm{C}} 36.6\right]$ to $\mathrm{C}-3\left(\delta_{\mathrm{C}}\right.$ $59.8), \mathrm{C}-8$ and $\mathrm{C}-16\left(\delta_{\mathrm{C}} 168.4\right)$. Furthermore, a correlation was also observed in COSY between $\mathrm{H}-11 \leftrightarrow \mathrm{H}-10$.

The ${ }^{13} \mathrm{C}$ NMR showed one primary diaminic and one quaternary carbon linker between two monomers of the dimer attributed to C-2 and $\mathrm{C}-3$, respectively. The $\mathrm{HMBC}$ spectrum presented a correlation between $\mathrm{H}-2$ and $\mathrm{H}-10 \mathrm{~b}\left[\delta_{\mathrm{H}} 2.80(d d, J=14.0 ; 8.5 \mathrm{~Hz})\right]$ with the carbon joining the dimeric C-3. The relative configuration of $\mathbf{3}$ was determined by 2D NMR experiments including NOESY spectra and in comparison with spectral data reported in the literature. ${ }^{12}$ Compound 3 was thus identified as dimer diketopiperazine WIN 64821 previously isolated from the endophytic fungus Aspergillus sp. in $1993\left([\alpha]_{\mathrm{D}}=+200.0(c 0.15, \mathrm{MeOH})\right)$. Nonetheless, in our case, the optical rotation values of $\mathbf{3}$ was $[\alpha]^{26}{ }_{\mathrm{D}}+350.0(c \quad 0.20$, $\mathrm{MeOH})$, respectively. Accordingly, this result implies that compound $\mathbf{3}$ has the same absolute configuration as the compound isolated from Aspergillus sp. ${ }^{9}$

The molecular formula $\mathrm{C}_{20} \mathrm{H}_{19} \mathrm{~N}_{3} \mathrm{O}_{3}$ of compound 4 was 
Table 1. ${ }^{1} \mathrm{H}$ - and ${ }^{13} \mathrm{C}$ NMR data for compounds $\mathbf{1}, 5$ and $6\left(500 \mathrm{MHz}, \mathrm{CDCl}_{3}\right)$

\begin{tabular}{|c|c|c|c|c|c|c|c|c|}
\hline \multirow{2}{*}{ Position } & \multicolumn{2}{|c|}{1} & \multirow{2}{*}{ Position } & \multicolumn{2}{|c|}{5} & \multirow{2}{*}{ Position } & \multicolumn{2}{|c|}{6} \\
\hline & $\delta{ }^{1} \mathrm{H}$ & $\delta^{13} \mathrm{C}$ & & $\delta{ }^{1} \mathrm{H}$ & $\delta^{13} \mathrm{C}$ & & $\delta{ }^{1} \mathrm{H}$ & $\delta^{13} \mathrm{C}$ \\
\hline 1 & - & 171.9 & 2 & - & 161.8 & 1 & - & 130.4 \\
\hline 3 & $5.35(s)$ & 69.3 & 4 & - & 147.3 & 2 & $7.29(d, 2.0)$ & 116.6 \\
\hline 4 & - & 155.2 & 5 & - & 111.3 & 3 & - & 154.6 \\
\hline 5 & $7.36(\mathrm{br} d, 8.0)$ & 117.1 & 6 & - & 153.4 & 4 & - & 137.6 \\
\hline 6 & $7.56(t, 8.0)$ & 132.3 & 8 & $7.80(s)$ & 138.1 & 5 & $7.38(d, 8.0)$ & 126.9 \\
\hline 7 & $7.41(\mathrm{br} d d, 8.0 ; 0.5)$ & 117.7 & 2 ' & $4.67(d, 6.5)$ & 42.0 & 6 & $7.33(d d, 8.0 ; 2.0)$ & 119.7 \\
\hline 8 & - & 127.7 & 3' & $5.21(t, 6.5)$ & 118.6 & 7 & - & 74.8 \\
\hline 9 & - & 136.2 & 4 ' & - & 136.5 & 8 & $\begin{array}{c}1.65(d t, 13.0 ; 4.5) \\
1.94(d d d, 13.0 ; 4.0 \\
3.5)\end{array}$ & 41.3 \\
\hline \multirow[t]{7}{*}{10} & $3.90(s)$ & 57.0 & 5 , & $1.78(d, 1.0)$ & 18.3 & 9 & $\begin{array}{l}0.99(m) \\
1.27(m)\end{array}$ & 21.3 \\
\hline & & & 6' & $1.66(d, 1.0)$ & 25.7 & 10 & $1.04(\mathrm{~m})$ & 38.8 \\
\hline & & & $\mathrm{C}-2-\mathrm{OH}$ & $6.77(s l)$ & - & 11 & $1.42(\mathrm{~m})$ & 27.2 \\
\hline & & & & & & 12 & $0.76(d, 3.0)$ & 22.5 \\
\hline & & & & & & 13 & $0.75(d, 2.5)$ & 22.3 \\
\hline & & & & & & 14 & $1.50(s)$ & 28.3 \\
\hline & & & & & & 15 & - & 167.4 \\
\hline
\end{tabular}

established by ${ }^{13} \mathrm{C}$ NMR and HREIMS analyses, and was found to depict the protonated molecular ion peak $[\mathrm{M}+\mathrm{H}]^{+}$at $\mathrm{m} / z, 350.1412$ (Calcd. to $\mathrm{C}_{20} \mathrm{H}_{19} \mathrm{~N}_{3} \mathrm{O}_{3} 350.3910$ ), indicating thirteen degrees of unsaturation.

The ${ }^{1} \mathrm{H}$ NMR spectra of $\mathbf{4}$ presented similar features as those in 2 and 3 , with the difference being in C-2 $\left(\delta_{\mathrm{C}} 84.1\right), \mathrm{C}-3\left(\delta_{\mathrm{C}} 86.0\right)$ and $\mathrm{C}-10\left(\delta_{\mathrm{C}} 41.5\right)$, which suggest that the protons $\mathrm{H}-2\left[\delta_{\mathrm{H}} 5.26(d, J=\right.$ $4.0 \mathrm{~Hz})]$ and $\mathrm{H}-10\left[\delta_{\mathrm{H}} 2.39(d d, J=13.0 ; 6.5 \mathrm{~Hz}, \mathrm{H}-10 \mathrm{a})\right.$ and 1.72
( $d d, J=13.0 ; 11.5 \mathrm{~Hz}, \mathrm{H}-10 \mathrm{~b})]$ are, in essence, neighbors of the carbon attached to oxygen, confirming the hydroxyl group bonded to $\mathrm{C}-3$. The absolute configuration of C-11 was based on that of the cyclic (L,L)-dipeptide (2). Compound $\mathbf{4}$ was thus identified as 3-hydroxy-15H-tryptophenaline, being the first report of its kind related to the isolation of this compound as a natural product and found only as a synthesis product. ${ }^{10}$

The molecular formula $\mathrm{C}_{10} \mathrm{H}_{13} \mathrm{~N}_{5} \mathrm{O}$ of compound $\mathbf{5}$ was established

Table 2. ${ }^{1} \mathrm{H}$ - and ${ }^{13} \mathrm{C}$ NMR data for compounds 2-4 $\left(500 \mathrm{MHz}, \mathrm{CDCl}_{3}\right)$

\begin{tabular}{|c|c|c|c|c|c|c|}
\hline \multirow{2}{*}{ Position } & \multicolumn{2}{|c|}{2} & \multicolumn{2}{|l|}{3} & \multicolumn{2}{|c|}{4} \\
\hline & $\delta^{1} \mathrm{H}$ & $\delta^{13} \mathrm{C}$ & $\delta^{1} \mathrm{H}$ & $\delta^{13} \mathrm{C}$ & $\delta{ }^{1} \mathrm{H}$ & $\delta^{13} \mathrm{C}$ \\
\hline NH-1 & $10.9(s)$ & - & - & - & $6.63(d, 4.0)$ & - \\
\hline 2 & $6.95(d, 2.5)$ & 124.4 & $4.95(s)$ & 79.8 & $5.26(d, 4.0)$ & 84.1 \\
\hline 3 & - & 108.8 & - & 59.8 & - & 86.0 \\
\hline 4 & $7.48(d, 8.0)$ & 118.7 & $7.34(d, 7.0)$ & 125.7 & $7.15(d d, 8.0 ; 2.0)$ & 122.6 \\
\hline 5 & $6.98(d d, 8.0 ; 7.0)$ & 118.4 & $6.81(d d d, 8.0 ; 7.0 ; 0.5)$ & 119.9 & $6.64(d d, 7.5 ; 6.5)$ & 117.9 \\
\hline 6 & $7.06(d d d, 8.0 ; 7.0 ; 0.5)$ & 120.9 & $7.19(d d d, 8.0 ; 8.0 ; 1.0)$ & 129.7 & $7.03(t d, 7.5 ; 7.5 ; 1.5)$ & 129.1 \\
\hline 7 & $7.31(d, 8.0)$ & 111.3 & $6.69(d d, 8.0 ; 0.5)$ & 110.1 & $6.53(\mathrm{brd}, 8.0)$ & 109.9 \\
\hline 8 & - & 127.5 & - & 129.8 & - & 131.2 \\
\hline 9 & - & 136.0 & - & 148.7 & - & 148.6 \\
\hline 10 & $\begin{array}{l}2.52(d d, 14.5 ; 6.0) \\
2.80(d d, 14.5 ; 4.0)\end{array}$ & 29.7 & $\begin{array}{l}3.17(d d, 14.0 ; 8.5) \\
2.80(d d, 14.0 ; 8.5)\end{array}$ & 36.6 & $\begin{array}{c}2.39(d d, 13.0 ; 6.5) \\
1.72(d d, 13.5 ; 11.5)\end{array}$ & 41.5 \\
\hline 11 & $3.96(m)$ & 55.2 & $3.95(t d, 8.5 ; 8.5 ; 1.0)$ & 57.1 & $4.60(d d, 11.5 ; 5.5)$ & 58.6 \\
\hline NH-12 & $7.89(d, 2.5)$ & - & - & - & - & - \\
\hline 13 & - & 166.2 & - & 167.4 & - & 167.4 \\
\hline 14 & $3.85(m)$ & 55.6 & $4.06(d d d, 10.5 ; 3.5 ; 1.0)$ & 56.4 & $4.45(t, 5.5)$ & 55.7 \\
\hline NH-15 & $7.69(d, 2.0)$ & - & $5.42(s)$ & - & $7.95(s)$ & - \\
\hline 16 & - & 166.8 & - & 168.4 & - & 169.9 \\
\hline 17 & $\begin{array}{l}1.85(d d, 13.0 ; 7.0) \\
2.45(d d, 13.0 ; 4.5)\end{array}$ & 40.6 & $\begin{array}{c}3.48(d d, 14.5 ; 3.5) \\
2.64(d d, 14.5 ; 10.5)\end{array}$ & 36.6 & $\begin{array}{l}3.04(d d, 14.5 ; 5.5) \\
3.16(d d, 16.0 ; 5.5)\end{array}$ & 34.7 \\
\hline 18 & - & 136.5 & - & 135.4 & - & 137.6 \\
\hline 19 & $7.15(m)$ & 128.0 & $7.26(d, 7.0)$ & 128.9 & $7.21(\mathrm{brd}, 8.0 ; 1.5)$ & 128.1 \\
\hline 20 & $6.70(d d, 8.0 ; 1.5)$ & 129.7 & $7.10(d d, 7.0 ; 1.5)$ & 129.3 & $7.34(t, 8.0)$ & 129.9 \\
\hline 21 & $7.17(m)$ & 126.3 & $7.23(t d, 7.0 ; 7.0 ; 1.5)$ & 127.6 & $7.15(t d, 8.0 ; 7.0 ; 7.0)$ & 126.4 \\
\hline 22 & $6.70(d d, 8.0 ; 1.5)$ & 129.7 & $7.10(d d, 7.0 ; 1.5)$ & 129.3 & $7.34(t, 8.0)$ & 129.9 \\
\hline 23 & $7.15(m)$ & 128.0 & $7.26(d, 7.0)$ & 128.9 & $7.21(\mathrm{brd}, 8.0 ; 1.5)$ & 128.1 \\
\hline
\end{tabular}


by ${ }^{13} \mathrm{C}$ NMR and HREIMS analyses, showing the protonated molecular ion peak $[\mathrm{M}+\mathrm{H}]^{+}$at $m / z, 220.1215$ (Calcd. to $\mathrm{C}_{10} \mathrm{H}_{13} \mathrm{~N}_{5} \mathrm{O} 220.1198$ ) and the ion peak [M-Prenyl] ${ }^{+}$at $m / z, 152.0578$, while indicating seven degrees of unsaturation.

The ${ }^{1} \mathrm{H}$ and ${ }^{13} \mathrm{C}$ NMR spectra of 5 indicated the presence of thirteen protons, including a methine proton $\left[\delta_{\mathrm{H}} 5.21(t, J=6.5 \mathrm{~Hz}\right.$, $\left.\left.\mathrm{H}-3^{\prime}, \delta_{\mathrm{C}} 118.6\right)\right]$, a methylene proton $\left[\delta_{\mathrm{H}} 4.67\left(d, J=6.5 \mathrm{~Hz}, \mathrm{H}-2\right.\right.$ ', $\delta_{\mathrm{C}}$ $42.0)]$, two methyl groups in $\left[\delta_{\mathrm{H}} 1.78\left(d, J=1.0 \mathrm{~Hz}, \mathrm{H}-5, \delta_{\mathrm{C}} 18.3\right)\right.$ and $\left.1.66\left(d, J=1.0 \mathrm{~Hz}, \mathrm{H}-6^{\prime}, \delta_{\mathrm{C}} 25.7\right)\right]$. The four aforementioned protons (H-2', H-3', H-5' and H-6') indicated the presence of a prenylated unit bonded to nitrogen. In addition, a methine proton $\left[\left(\delta_{\mathrm{H}} 7.80(s\right.\right.$, $\left.\left.\mathrm{H}-8, \delta_{\mathrm{C}} 138.1\right)\right]$ was also observed, thus suggesting the presence of an aromatic ring.

The ${ }^{13} \mathrm{C}$ NMR spectra showed the presence of four quaternary aromatic carbons with one oxygenated and one $\mathrm{sp}^{2}$ methine cyclic carbon (C-8) attached to nitrogen suggesting the presence of the purine base 2-hydroxy-adenine. The proton $\mathrm{H}-2$ ' in the prenylated unit showed HMBC correlations with C-6 $\left(\delta_{\mathrm{C}} 153.4\right)$, implying that the group is attached to $\mathrm{C}-6$. Compound $\mathbf{5}$ was identified as 2-hydroxy6-N-isopentenyl-adenine, being the first report of its kind related to the isolation of this compound as a natural product and found only as a synthesis product. ${ }^{11}$

The molecular formula $\mathrm{C}_{15} \mathrm{H}_{22} \mathrm{O}_{4}$ of compound 6 was established by ${ }^{13} \mathrm{C}$ NMR and ES-MS (+) analyses, showing the $\mathrm{m} / \mathrm{z} 289.0$ $(100 \%)[\mathrm{M}+\mathrm{Na}]^{+}$and $\mathrm{m} / \mathrm{z}, 821[3 \mathrm{M}+\mathrm{Na}]^{+} ; \mathrm{m} / \mathrm{z}, 555[2 \mathrm{M}+\mathrm{Na}]^{+}$and $\mathrm{m} / \mathrm{z}$ $\left[\mathrm{M}-2 \mathrm{H}_{2} \mathrm{O}+\mathrm{H}\right]^{+}$, and indicating five degrees of unsaturation.

The ${ }^{1} \mathrm{H}$ NMR spectra indicated the presence of three aromatic signals at $\delta_{\mathrm{H}} 7.38\left(d, J=8.0 \mathrm{~Hz}, \mathrm{H}-5, \delta_{\mathrm{C}} 126.9\right) 7.33(d d, J=8.0,2.0$ $\left.\mathrm{Hz}, \mathrm{H}-6, \delta_{\mathrm{C}} 119.7\right)$, and $7.29\left(d, J=2.0 \mathrm{~Hz}, \mathrm{H}-2, \delta_{\mathrm{C}} 116.6\right)$, indicating the aromatic system 1,2,4-trisubstituted ring. A further observation worth noting was that the ${ }^{1} \mathrm{H}$ NMR showed signals at $\delta_{\mathrm{H}} 0.76(d, J=$ $\left.3.0 \mathrm{~Hz}, \mathrm{H}-12, \delta_{\mathrm{C}} 22.5\right), \delta_{\mathrm{H}} 0.75\left(d, J=2.5 \mathrm{~Hz}, \mathrm{H}-13, \delta_{\mathrm{C}} 22.3\right)$ and $\delta_{\mathrm{H}}$ $1.50\left(s, \mathrm{H}-14, \delta_{\mathrm{C}} 28.3\right)$, characteristic of methyl groups and a group of the methylene proton at $\delta_{\mathrm{H}} 0.99-1.94(\mathrm{H}-8$ to $\mathrm{H}-10)$, respectively, indicating the presence of a 1-hydroxy-1,5-dimethyl-hexyl. This moiety could be observed through the analyses of the COSY and HMBC spectrum.

The ${ }^{13} \mathrm{C}$ NMR showed six aromatic carbons among which one was found to be oxygenated $\left(\delta_{\mathrm{C}} 154.6, \mathrm{C}-3\right)$, two substituted $\left[\left(\delta_{\mathrm{C}} 137.6\right.\right.$, $\mathrm{C}-4)$ and $\left.\left(\delta_{\mathrm{C}} 130.4, \mathrm{C}-1\right)\right]$ and three protonated $\left[\left(\delta_{\mathrm{C}} 126.9, \mathrm{C}-5\right),\left(\delta_{\mathrm{C}}\right.\right.$ $119.7, \mathrm{C}-6)$ and $\left.\left(\delta_{\mathrm{C}} 116.6, \mathrm{C}-2\right)\right]$, one carboxylic carbon $\left(\delta_{\mathrm{C}} 167.4\right.$, $\mathrm{C}-15)$, one quaternary carbon attached to oxygen $\left(\delta_{\mathrm{C}} 74.8, \mathrm{C}-7\right)$, a group of aliphatic methylene and methine $\left[\left(\delta_{\mathrm{C}} 41.3, \mathrm{C}-8\right),\left(\delta_{\mathrm{C}} 21.3\right.\right.$, $\mathrm{C}-9),\left(\delta_{\mathrm{C}} 38.8, \mathrm{C}-10\right)$ and $\left.\left(\delta_{\mathrm{C}} 27.2, \mathrm{C}-11\right)\right]$ and three methyl groups $\left[\left(\delta_{\mathrm{C}} 22.5, \mathrm{C}-12\right),\left(\delta_{\mathrm{C}} 22.3, \mathrm{C}-13\right)\right.$ and $\left.\left(\delta_{\mathrm{C}} 28.3, \mathrm{C}-14\right)\right]$.

The positioning of the carboxylic acid, hydroxyl and the hexyl substituents in the aromatic ring were based on correlations observed in HMBC between H-2/H- $6 \leftrightarrow \mathrm{C}-15, \mathrm{H}-5 \leftrightarrow \mathrm{C}-3 / \mathrm{C}-7$, and $\mathrm{H}-14 \leftrightarrow \mathrm{C}-4$. Compound 6 was thus identified as 3-hydroxy-4-(1-hydroxy-1,5dimethyl-hexyl) benzoic acid or sydonic acid previously isolated from the endophytic fungus A. sydowi in 1978 as a racemate, while (+)-sydonic acid $\left([\alpha]^{25}+2.73(c\right.$ 2.30, MeOH$\left.)\right)$ was isolated from Glonium sp. in 2009. It is worth pointing out, however, that in our case, the optical rotation values of 6 were $[\alpha]^{26}{ }_{\mathrm{D}}+1.43(c 1.40$, $\mathrm{MeOH})$, respectively. Given that there was only one chiral carbon in every compound, the absolute configuration of this compound (6) was also established to be $S$. Interestingly, (-)-sydonic acid had also been recently isolated from a coral-derived Aspergillus sp. $[\alpha]_{\mathrm{D}}^{25}$ $-2.0\left(\right.$ c $\left.1.03, \mathrm{CHCl}_{3}\right) .{ }^{12}$

The diketopiperazines (DKPs) comprise an important family of the secondary metabolites that are mainly produced by plants and microorganisms. A huge number of tryptophan-based dimeric diketopiperazine (DKP) alkaloids which have been isolated from fungi have meaningfully brought to the fore fascinating biological activities,<smiles>COc1cccc2c1COC2=O</smiles>

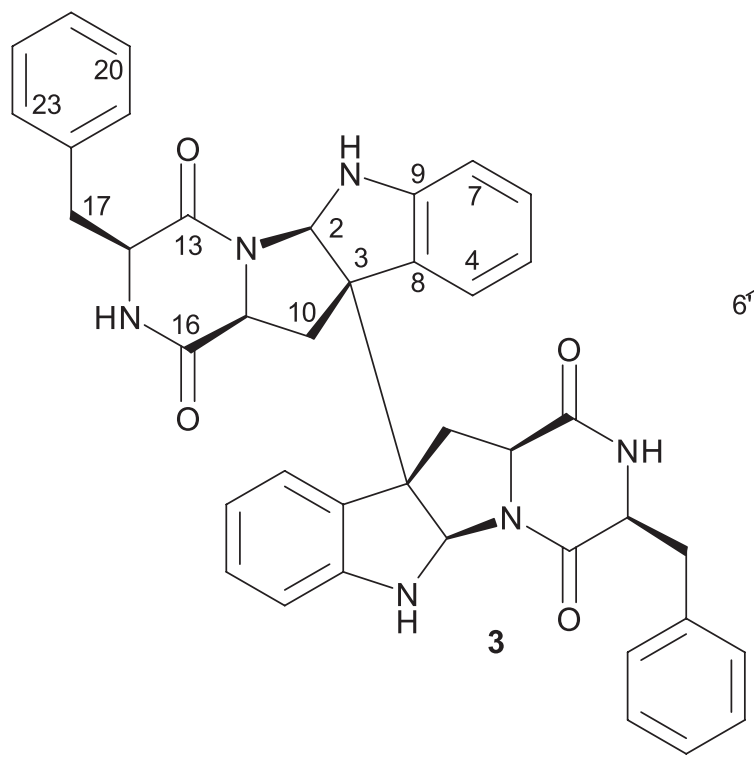<smiles>O=C1N[C@H](Cc2c[nH]c3ccccc23)C(=O)N[C@@H]1Cc1ccccc1</smiles><smiles>C=C1N[C@H](Cc2ccccc2)C(=O)N2C3Nc4ccccc4[C@]3(O)C[C@H]12</smiles><smiles>C/C([13CH3])=C\CNc1nc(O)nc2[nH]cnc12</smiles><smiles>CC(=O)c1ccc(C(C)(C)C)c(O)c1</smiles>

Figure 1. Compounds isolated from A. versicolor 
including plant growth regulation and cytotoxicity, paving the way essentially towards their potential application in pharmaceutical and agricultural industries.

As one of the DKPs, cyclo (L-Trp-L-Phe) has notably the biological activities of plant growth regulation and moderate cytotoxicity. In addition, cyclo (L-Trp-L-Phe) is most likely the biosynthetic precursor to complex diketopiperazine WIN 64821, a nonpeptide neurokinin antagonist. By virtue of that, we believe that it has the application potential in both pharmaceutical and agricultural biotechnologies. Admittedly, despite the fact that compound $\mathbf{4}$ has been prepared synthetically, the findings of this study cannot be, in the least bit, underestimated given that this is the first report of its kind that unfolded the production of this metabolite as a natural product and most importantly from microorganisms.

\section{CONCLUSION}

This is the first account of the cultivation of A. versicolor in potato dextrose broth which produced tryptophan-based dimeric diketopiperazine (DKP) alkaloids. Cyclodipeptides with a prenylated indole group, structurally characterized by a diketopiperazine (DKP) ring, bicyclo[2,2,2]-diazaoctane ring, or 1,7-dihydropyrano-[2,3-g] indole ring system, such as brevianamides, paraherquamides, stephacidins, versicolamides, and carneamides, are widely distributed in terrestrial and marine-derived microorganisms, especially in the genera Aspergillus. Nonetheless, these compounds were isolated following the cultivation of $A$. versicolor in two liquid culture media, one being composed of dextrose, yeast extract, $\mathrm{KH}_{2} \mathrm{PO}_{4}$, $\mathrm{MgSO}_{4} \cdot 7 \mathrm{H}_{2} \mathrm{O}$, and potato extract, ${ }^{13}$ and the other one consisting of maltose, mannitol, glucose, peptone, yeast extract, potato, and seawater and in solid medium containing rice, soya bean powder and artificial seawater. ${ }^{14}$

Furthermore, when the fungus A. versicolor was cultivated in potato dextrose broth, it was found to produce butyrolactones. The results obtained reinforce the observations that microorganism metabolic production is dependent on culture medium. With this work, we seek to highlight the imperative urgency regarding the study of this niche of microorganisms in the face of the increasing rate of extinction of Brazilian plant species.

\section{ACKNOWLEDGMENTS}

The authors would like to express their sincerest gratitude and indebtedness to the Brazilian Research Funding Agencies - Fundação de Amparo à Pesquisa do Estado de São Paulo (FAPESP - process \#03/02176-7 and 2013/07600-3) and CNPq (process \#563286/20105) for the funds granted in the course of this research. JRG, HLT and GHS are also extremely grateful to CNPq and CAPES for awarding the Ph.D. scholarships. Our thanks also go to the British native English language content editor - J. Brian Newmann for his painstaking editing and proofreading services provided.

\section{REFERENCES}

1. Staniek, A.; Woerdenbag, H. J.; Kayser, O.; J. Plant Interact. 2008, 3, 75; Kusari, S.; Pandey, S. P.; Spiteller, M.; Phytochemistry 2013, 91, 81.

2. Devari, S.; Jaglan, S.; Kumar, M.; Deshidi, R.; Guru, S.; Bhushan, S.; Kushwaha, M.; Gupta, A. P.; Gandhi, S. G.; Sharma, J. P.; Taneja, S. C.; Vishwakarma, R. A.; Shah, B. A. Phytochemistry 2014, 98, 183; Zheng, C.-J.; Xu, L.-L.; Li, Y.-Y.; Han, T.; Zhang, Q.-Y.; Ming, Q.-L.; Rahman, K.; Qin, L.-P.; Appl. Microbiol. Biotechnol. 2013, 97, 7617.

3. Chu, D.; Peng, C.; Ding, B.; Liu, F.; Zhang, F.; Lin, H.; Li, Z.; Bioprocess. Biosyst. Eng. 2011, 34, 223; Li, X.; Dobretsov, S.; Xu, Y.; Xiao, X.; Hung, O. S.; Qian, P.-Y.; Biofouling 2006, 22, 187.

4. Oliveira, C. M.; Regasini, L. O.; Silva, G. H.; Pfenning, L. H.; Young, M. C. M.; Berlinck, R. G. S.; Bolzani, V. S.; Araujo, A. R.; Phytochem. Lett. 2011, 4, 93.

5. Silva, G. H.; Teles, H. L.; Trevisan, H. C.; Young, M. C. M.; Pfenning, L. H.; Eberlin, M. N.; Haddad, R.; Costa Neto, C.; Bolzani, V. S.; Araujo, A. R.; J. Braz. Chem. Soc. 2005, 16, 1463; Teles, H. L.; Silva, G. H.; Castro-Gamboa, I.; Bolzani, V. S.; Pereira, J. O.; Costa Neto, C.; Haddad, R.; Eberlin, M. N.; Young, M. C. M.; Araujo, A. R.; Phytochemistry 2005, 66, 2363; Cafêu, M. C.; Silva, G. H.; Teles, H. L.; Bolzani, V. S.; Araujo, A. R.; Young, M. C. M.; Pfenning, L. H.; Quim. Nova 2005, 28, 991; Silva, G. H.; Teles, H. L.; Zanardi, L. M.; Young, M. C. M.; Haddad, R.; Eberlin, M. N.; Pfenning, L. H.; Costa Neto, C. M.; Castro-Gamboa, I.; Bolzani, V. S.; Araujo, A. R.; Phytochemistry 2006, 67, 964.

6. Egan, B. A.; Paradowski, M.; Thomas, L. H.; Marquez, R.; Org. Lett. 2011, 13, 2086

7. Wang, J.; Wang, G.; Zhang, Y.; Zheng, B.; Zhang, C.; Wang, L.; World J. Microbiol. Biotechnol. 2014, 30, 2639; Fotso, S.; Mahmud, T.; Zabriskie, T. M.; Santosa, D. A.; Sulastri; Proteau, P. J.; J. Antibiotic. 2008, 61, 449 .

8. Kimura, Y.; Tani, K.; Kojima, A.; Sotoma, G.; Okada, K.; Shimada, A.; Phytochemistry 1996, 41, 665.

9. Barrow, C. J.; Cai, P.; Snyder, J. K.; Sedlock, D. M.; Sun, H. H.; Cooper, R.; J. Org. Chem. 1993, 58, 6016.

10. Maes, C. M.; Potgieter, M.; Steyn, P. S.; J. Chem. Soc., Perkin Trans. 1 1986, 6,861 .

11. Myles, A.; Fox, J.; J. Med. Chem. 1968, 11, 143.

12. Hamasaki, T.; Nagayama, K.; Hatsuda, Y.; Agric. Biol. Chem. 1978, 1, 37; Zheng, C.; Shao, C.-L.; Wang, K.-L.; Zhao, D.-L.; Wang, Y.N.; Wang, C.-Y.; Zhongguo Haiyang Yaowu 2012, 31, 7; Kudo, S.; Murakami, T.; Miyanishi, J.; Tanaka, K.; Takada, N.; Hashimoto, M.; Biosci. Biotechnol. Biochem. 2009, 73, 203.

13. Li, G.-Y.; Yang, T.; Luo, Y.-G.; Chen, X.-Z.; Fang, D.-M.; Zhang, G.-L.; Org. Lett. 2009, 11, 3714; Peng, J.; Gao, H.; Li, J.; Ai, J.; Geng, M.; Zhang, G.; Zhu, T.; Gu, Q.; Li, D.; J. Org. Chem. 2014, 79, 7895; Song, F.; Liu, X.; Guo, H.; Ren, B.; Chen, C.; Piggott, A. M.; Yu, K.; Gao, H.; Wang, Q.; Liu, M.; Liu, X.; Dai, H.; Zhang, L.; Capon, R. J.; Org. Lett. 2012, 14, 4770

14. Zhou, M.; Lou, J.; Li, Y.-K.; Wang, Y.-D.; Zhou, K.; Ji, B.-K.; Dong, W.; Gao, X.-M.; Du, G.; Hu, Q.-F.; J. Braz. Chem. Soc. 2015, 26, 545 